\title{
Increasing Speaking Skills Through the Drama Method in Class IV Students of SD Unggulan Putra Kaili Permata Bangsa
}

\author{
Iriyanti Iriyanti ${ }^{*}$, Muhammad Darwis ${ }^{2}$ \\ ${ }^{1.2}$ Faculty of Cultural Sciences, Hasanuddin University \\ *Corresponding author.Email: iriyantips77@gmail.com
}

\begin{abstract}
That aims to improve speaking skills through the drama method in fifth-grade students of SD Unggulan Putra Kaili Permata Bangsa. This research is a classroom. The subjects of this study were class IV students in the 2020/2021 academic year as many as 16 students consisting of 9 boys and 7 girls. Preliminary observation results show that 77\% of fifth-grade students at SD Unggulan Putra Kaili Permata Bangsa do not yet have good speaking skills. The average score of student learningoutcomes after the action in the first cycle was 71.15. The number of students whohave completed the first cycle is 9 people or $56.25 \%$ and 7 people who have not completed or $43.75 \%$. After being continued in cycle II, the average score of studentlearning outcomes on speaking subject matter was $79.85 \%$. With the number of students who have passed in this cycle, there are 14 people or $87.50 \%$ and 2 peoplewho have not passed or $12.50 \%$. Based on the results of the assessment of speakingskills in the first cycle of action, the pronunciation aspect averages 71.50 , the intonation aspect averages 71.50 , the fluency aspect averages 77.75, and theexpression aspect averages 76.00. Of the four aspects assessed, 2 of them did not reach the KKM (75) two aspects had reached the KKM but were not satisfactory. The factor causing the first cycle is that the students' activity in learning has not been maximized so that it affects their speaking ability. Efforts are made in the nextaction is to improve the detailed learning scenario and maximize student potential by motivating students. The results of the second cycle of action, the pronunciationaspect is 82.70 , the intonation aspect is 88.75 , the fluency aspect is 90.30 , and the expression aspect is 83.75 . Overall, it has reached the KKM so that the learning is declared successful.
\end{abstract}

Keywords: Speaking Skills, Drama Method

\section{INTRODUCTION}

The 2013 curriculum requires several subjects to be integrated into one learning, where everything is interconnected. One of the subject content is Indonesian. Besides being used as a subject matter, usually Indonesian is also onlyused as an introductory or introductory course, because within the scope of learning Indonesian several language skills are very important for smooth learning. Therefore, language is very important because it can be used to communicate in everyday life. Concerning the use of language topics, four aspects of language skillscan be used for fluency in communication in everyday life, namely writing skills, reading skills, speaking skills, and listening skills [1].

Speaking as a language skill is needed for various purposes. We are required to have the provision of speaking skills so that at any time we need to be able to convey information to anyone properly. These speaking activities can be done individually, in pairs, or in groups. By mastering speaking skills, students can expresstheir thoughts and feelings intelligently according to the context and situation whenthey are speaking.

Someone who has speaking skills will find it easier to convey ideas or ideas to others. The success of using the idea so that it can be accepted by the person who is listening or being spoken to, on the other hand, someone who cannot speak will have difficulty conveying ideas to others. Children are environmental products if the environment often invites talk, always answers and pays attention to the questions asked, and the environment provides development opportunities forchildren, the child will be skilled at speaking, on the contrary, if parents, family members, and the community do not provide opportunities for child development, the child will have difficulty speaking.

Speaking is a behaviour that must be learned first, then it can be mastered. Speaking skill is a mechanistic skill, the more you practice, the more mastered andskilled a person will be in speaking. 
No one is immediately skilled in speaking without going through the process of practising. In learning and practising speaking, a person needs to be trained: pronunciation, voice control, selfcontrol, controlling body movements, choosing words, sentences and intonation, using good and correct language, and organizing or organizing ideas [2].

Speaking is a skill, and the skill will not develop if it is not practised continuously. The ability to speak is part of the basic literacy of the national literacyprogram that must be possessed by students in improving learning in the classroom. Therefore, the ability to speak will not be mastered properly without practice. If youalways practice, speaking skills will certainly get better. On the other hand, if you are embarrassed, doubtful, or afraid of being wrong in practicing speaking, your intelligence or speaking skills will certainly get further and further mastery. In this environment, students are required to be skilled in speaking in the learning process.Students must be able to express their ideas. They must also be able to answer questions or ask questions well during the learning process [3].

Speaking skills in Indonesian subjects direct each student to improve the abilityto communicate orally properly and correctly in front of the public. To achieve this, of course, students are also required to be skilled in speaking in the learning process. Students must be able to express their ideas or opinions. They must also be able to answer questions or ask questions well during the learning process. Likewise, in storytelling, students must be able to tell stories well and confidently because storytelling is one of the most important speaking skills to practice communicationand the courage to appear in public [4].

Speaking skills are language skills that emphasize aspects of expressing ideas, feelings, and thoughts through speech. Other language skills such as writing, listening and reading [5]. Tarigan [6] says that speaking is the ability to pronounce articulation sounds or words to express, state, and convey thoughts, ideas, and feelings [6]. Speaking is the skill of conveying messages through spoken language. From these two opinions, it can be said that speaking is a person's ability to convey thoughts, ideas, and feelings using spoken language by Djago Tarigan in Rahman [6].

According to Yunus [7] the first challenge for teachers in implementinglearning in the context of the 2013 curriculum is that teachers must teach so that students can construct meaning. This means that the concept of teacher-based learning must be abandoned. Teachers must be able to organize education oriented to student activities in finding and establishing meaning independently so that the learning process will be able to form higher-order thinking skills in students. This view is in line with the constructivist perspective which assumes that knowledge must be personal so that its meaning can be constructed by students through experience. Therefore, learning must be interpreted as a social and cultural activity where students construct meaning which is influenced by the interaction between previous knowledge and recent events. Learning should be focused not on how individuals try to understand a phenomenon, but also on the social role of learningmedia.

Ningsih [8] says that constructivism is an approach that shows that learningis more effective and meaningful when students can interact with problems or concepts. Zamani in Ningsih [8] argues that this approach allows students to build knowledge, integrate it into new situations, take their prior knowledge as thebasis and benefit from social interaction and develop critical thinking. In other words, he views that instead of passive recipients waiting for the teacher to provide a stimulus to elicit a response, the learner is responsible for his or her learning. Constructivist learning is usually associated with a learnercentred approach, where students actively participate in meaningful activities. Therefore, students are not "empty cans to be filled with knowledge, but dynamic organisms seeking meaning." [8]. Learning outcomes of both cognitive processes and social interactions. That is, in addition to the processes of perception, organization, and recall of information, constructivism also refers to the interactions in which learners learn with and from others.

Altun and Sabah [9] state that since the beginning of human children, theycollaborate for an equal determination to achieve their goals. The notion of cooperation has also been mentioned by Barfield in Altun [9] defining cooperative learning as "deciding goals together with" others, sharing responsibilities, and working together to achieve more than can be achieved by their individuals. Cooperation is not an easy grouping job, it also requires the ability to perform, take action, and take responsibility for those outcomes and consequences.In addition, cooperation has features depending on the skills and abilities of each. Ibrahim in Altun [9] makes students dependent on each other in the pursuit of knowledge and makes learning a more meaningful and interesting process.

Drama activities can be carried out through a learning model with the method of role-playing, puppet play, and drama performances. Roleplaying can be done either with a script that is already available or made by the students themselves, meanwhile, drama performances can also be done by students in class with all simplicity 
according to the class situation. ask questions properly during the lesson. When doing this process, students directly practice speaking Indonesian, not just memorizing vocabulary. The first step in learning with the practical method of drama and role-playing is that the teacher can choose a topic that can be dramatized, then the teacher asks the students to act it out.

Drama has a specialty compared to other literary genres. Drama text written bythe author does not only stop at the stage of exposing events to be enjoyed artistically imaginatively by the readers but must be continued to be shown in a concrete performance of motion and behaviour that can be witnessed. This particularity of drama then causes the notion of drama as a literary genre to be more focused as a work that is more oriented to the performing arts. Drama is not just tobe read, but created to be performed by an art group on stage. Bawana [10] Dramahas a specialty compared to other literary genres. Drama text written by the authordoes not only stop at the stage of exposing events to be enjoyed artistically imaginatively by the readers but must be continued to be shown in a concrete performance of motion and behaviour that can be witnessed. This particularity of drama then causes the notion of drama as a literary genre to be more focused as a work that is more oriented to the performing arts. Drama is not only meant to be read but created to be performed by an art group on the Bawana stage [10].

Drama plays an important role in human life because drama has several functions related to human life. Jazuli in Bawana [10] says that one of the functions of drama is as a means of entertainment. This function is reflected in theuse of art to provide entertainment or pleasure alone or used to fill spare time. Thefunction of drama as entertainment is to present stories about human life and history. Drama is a medium for staging stories in the twists and turns of life and local wisdom (human values, philosophy, love, and chivalry). Drama brings messages of humanity to society, as is the case with the arts of lenong, wayang, and ludruk. Drama has other functions, including as a means of communication, a means of providing knowledge about historical stories to the community, even as ameans of education. Drama is also used as a means to provide counseling, such as counseling about safety, the dangers of drugs, and health. Many also use drama as a means of protesting against the government.

According to Djafar [3], when students play roles, the teacher can observe students' skills in speaking on drama scripts using good and correct Indonesian. Indonesian is also the official language of instruction. This can be seen in the teaching and learning process that occurs at every level of education, both educators and students use
Indonesian as the language of instruction to transfer knowledge for educators and to gain knowledge for students.

Then the teacher as a facilitator will direct students to be able to speak skillfullythrough the role-playing method. Because by playing a role (drama) students will express ideas or ideas through their thoughts and feelings, spontaneously and experienced directly in the language. Speaking skills through drama will appear a sense of courage, confidence.

Haris in Tarigan [5] describes the components that need special attentionin the test (assessment) of four language skills. Assessment of speaking skills consists of four components, namely components of phonology, structure, vocabulary, and general fluency. In this study, the aspects assessed by the researcher were: a) pronunciation, b) intonation, c) fluency, d) expression.

\section{METHODS}

\subsection{Research Design}

This research uses classroom action research. Classroom Action Research (CAR) is scientific research that has two objectives, namely taking action for improvementand building knowledge or theory about action. The second dimension in action research is that the researcher collaborates with the subject under study, the subjectactively participates in the research cycle [11]. The research design uses the Coast model (Sugiono, 2015: 47) [11] which includes four steps in one cycle, namely Plan (plan), Act (implementation), Observe (observation), and Reflect (reflection).

\subsection{Data Collection}

In this classroom action research, the researcher used several data collection techniques, namely preliminary tests, observations, interviews, documentation studies, and final tests.

\subsection{Data Analysis}

Data analysis in Classroom Action Research was conducted during and after data collection. The collected data is then analyzed through the following stages: a) reducing data, b) presenting data, and c) concluding.

\section{RESULT AND DISCUSSION}

Based on the results of observations and assessments that have been carried out during the process of learning speaking skills for fourth-grade students of SD Unggulan Putra Kaili Permata Bangsa through the drama method, the results are asfollows: 
Table 1: Value of Pre-cycle Speaking Skills

\begin{tabular}{|l|c|c|}
\hline \multicolumn{1}{|c|}{ Value } & $\begin{array}{c}\text { Number of } \\
\text { Students }\end{array}$ & Percentage \\
\hline $\begin{array}{l}\text { Students didnot } \\
\text { complete }(\leq 70)\end{array}$ & 13 & $81,25 \%$ \\
\hline $\begin{array}{l}\text { Completed } \\
\text { student }(\geq \\
70)\end{array}$ & 3 & $18,75 \%$ \\
\hline Total & 16 & $100 \%$ \\
\hline
\end{tabular}

Table 1 shows that students who did not achieve mastery learning outcomeson speaking skills in the cycle were more than the scores of students who achievedmastery. Students who did not achieve completeness were 13 students $(81.25 \%)$, while students who achieved completeness were 3 students $(18.75 \%)$. The studentmastery guidelines used by SD Unggulan Putra Kaili Permata Bangsa are said to be complete if students' learning outcomes are $70 \%$ individually, and classically $75 \%$.Based on the pre-cycle results obtained, namely the large number of students who have not achieved the mastery of learning speaking skills, so it isnecessary to have the right method to improve speaking skills, namely by applying the drama method.

Table 2: Value of Speaking Skills Cycle I

\begin{tabular}{|l|c|c|}
\hline \multicolumn{1}{|c|}{ Value } & $\begin{array}{l}\text { Number of } \\
\text { Students }\end{array}$ & $\begin{array}{c}\text { Percen } \\
\text { tage }\end{array}$ \\
\hline $\begin{array}{l}\text { Students did not } \\
\text { complete }(\leq 70)\end{array}$ & 7 & $43,75 \%$ \\
\hline $\begin{array}{l}\text { Completed } \\
\text { student }(\geq 70)\end{array}$ & 9 & $56,25 \%$ \\
\hline Total & 16 & $100 \%$ \\
\hline
\end{tabular}

Table 2 shows that students have experienced changes, especially in speaking skills using the drama method in the first cycle. Students who achieve complete learning are 9 students $(56.25 \%)$. Students who have not achieved complete learning are 7 students (43.75\%). Learning outcomes in the first cycle showed an increase from pre-cycle activities even though the scores obtained by students bothindividually and classically were not maximized. Therefore, there need to be further improvements to student learning outcomes, namely doing the next stage in cycle II.

Table 3: Value of Speaking Skills Cycle II

\begin{tabular}{|c|c|c|}
\hline Value & $\begin{array}{c}\text { Number of } \\
\text { Students }\end{array}$ & Percentage \\
\hline $\begin{array}{l}\text { Students did not } \\
\text { complete }(\leq 70)\end{array}$ & 2 & $12,5 \%$ \\
\hline
\end{tabular}

\begin{tabular}{|l|c|c|}
\hline $\begin{array}{l}\text { Completed } \\
\text { student }(\geq 70)\end{array}$ & 14 & $87,5 \%$ \\
\hline Total & 16 & $100 \%$ \\
\hline
\end{tabular}

Based on the data in Table 3, student learning outcomes in speaking skills using thedrama method in cycle II were very good. Students who achieve complete learningare 14 (87.5\%), while those who do not achieve complete learning are 2 students $(12.5 \%)$. This has met the standard of student learning completeness so there is noneed for the next cycle to be held.

Based on the results of the speaking ability assessment in the first cycle of action, the average pronunciation aspect is 71.50 , the intonation aspect is 71.50 , the fluency aspect is 77.75 and the expression aspect is 76.00. Of the four aspects assessed, 2 of them did not reach the KKM (75) two aspects had reached the KKM but were not satisfactory. The factor causing the first cycle is that the students' activity in learning has not been maximized so that it affects their speaking ability. Efforts are made in the next action is to improve the detailed learning scenario andmaximize student potential by motivating students. The results of the second cycleof action, the pronunciation aspect is 82.70 , the intonation aspect is 88.75 , the fluency aspect is 90.30, and the expression aspect is 83.75 . Overall, it has reached the KKM so that the learning is declared successful.

\section{Conclusions and Suggestions}

Based on the results of the study, it can be concluded that the application of the drama method in learning Indonesian can improve the speaking skills of fourth-grade students of SD Unggulan Putra Kaili Permata Bangsa.

Several things need to be put forward as suggestions, namely (1) The researcher suggests that students, especially fourth graders of SD Unggulan Putra KailiPermata Bangsa to be more active in participating in Indonesian language and literature subjects as well as more exercises on drama scripts so that their abilities speaking can be further improved; (2) The school should provide learning facilities (supporting books on drama) related to Indonesian language and literature lessons. This will motivate and broaden students' knowledge to study harder with completebooks; (3) It is hoped that other researchers will conduct more complete research on speaking skills specifically using drama texts so that the results are even better.

\section{RESEARCH CONTRIBUTION}

\subsection{Theoretical Benefits}

The results of this study can contribute additional knowledge in learning in generaland learning in particular so that speaking skills can increase 
optimally.

\subsection{Practical Benefits}

Increasing students' interest and activity in learning speaking skills, students will experience fun and innovative learning.

For Teachers:

a. Teachers can apply the role-playing method in improving the learning of speaking skills in drama material.

b. Teachers can be motivated to apply varied and fun learning methods to achieve learning objectives.

For Schools:

a. The results of this study can improve the quality of the learning process at school, which is related to learning speaking skills in drama material with the role-playingmethod.

b. The results of this study can be used as a reference to innovative learning methods in schools.

c. The results of the study can also improve the quality of school education serviceswhich are increasing.

\section{ACKNOWLEDGMENT}

Praise and gratitude researchers pray to Allah SWT who always bestows His gifts so that this research can be completed. We extend our deepest gratitude to the Dean of the Faculty of Cultural Sciences, the Head of the Indonesian Literature Study Program, and the lecturers who have always guided researchers to complete this research.

\section{REFERENCES}

[1] Astiar dkk (2020) Speaking skills Through Project Based Learning at Elementary Schools. Jurnal Pendidikan Sekolah Dasar V01. 9. No.5.

[2] Slamet (2014) Pembelajaran Keterampilan Berbahasa Indonesia Teori dan Aplikasi. Yogyakarta : Graha Ilmu.

[3] Djafar (2020) Menstimulasi Kemampuan Berbicara Melalui Praktek. Drama pada Siswa Kelas XI SMA Negeri 1 Palopo. Andi Djemma|Jurnal Pendidikan, 3(1),2.

[4] Nupus (2017) Peningkatan Keterampilan Berbicara Melalui Penerapan Metode Show and Tell Siswa SD Negeri 3 Banjar Jawa.Jurnal IlmiahSekolah Dasar. Vol.1 (4) pp.198-203

[5] Tarigan Henry Guntur (2012) Berbicara sebagai suatu keterampilan Berbahasa. Bandung: Angkasa.
[6] Rahman Abd (2021) Gambar Idola untuk Meningkatkan Keterampilan Berbicara Siswa Kelas X SMA Negeri 1 Bantaeng.JPSS: Vol. 1 No. 1

[7] Abidin Yunus (2014) Desain Sistem Pembelajaran dalam Konteks Kurikulum 2013. Bandung : Rafika Aditama.

[8] Ningsih (2018) Aplikasi Teori Belajar Konstruktivisme dalam Pembelajaran Bahasa Asing. Foundasia, Vol IX No.1.

[9] Altun, Mustafa (2020) The Effect of Cooperative Learning Strategies in the Enhancement of EFL Learners' Speaking Skills, Asian EFL Journal Research Articles. Vol 27 Issue No.2.3. April 2020.

[10] Bawana, Ketut Adi. Gunatama, Gede. Astika I Made(2017) Proses Produksi Pementasan Drama Teater Angin SMA Negeri 1 Denpasar.e-Journal Universitas Pendidikan Ganesha Jurusan Pendidikan Bahasa dan Sastra Indonesia, Vol:6 No:1

[11] Sugiyono (2015) Metode Penelitian Tindakan Komprehensif. Bandung :Alfabeta 